\title{
Scanning Electron Microscopy
}

Volume 4

Number 1 The Science of Biological Specimen

Preparation for Microscopy and Microanalysis

Article 16

1985

\section{Low Temperature Embedding}

E. Carlemalm

University of Basel

W. Villiger

University of Basel

J. -D. Acetarin

University of Basel

E. Kellenberger

University of Basel

Follow this and additional works at: https://digitalcommons.usu.edu/electron

Part of the Biology Commons

\section{Recommended Citation}

Carlemalm, E.; Villiger, W.; Acetarin, J. -D.; and Kellenberger, E. (1985) "Low Temperature Embedding," Scanning Electron Microscopy. Vol. 4 : No. 1 , Article 16.

Available at: https://digitalcommons.usu.edu/electron/vol4/iss1/16

This Article is brought to you for free and open access by the Western Dairy Center at DigitalCommons@USU. It has been accepted for inclusion in Scanning Electron Microscopy by an authorized administrator of DigitalCommons@USU. For more information, please contact digitalcommons@usu.edu.

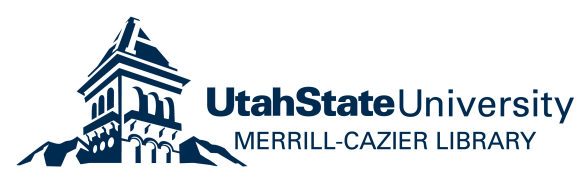


Science of Biological Specimen Preparation (pp. 147-154)

SEM Inc., AMF O'Hare (Chicago), IL 60666-0507, U.S.A.

LOW TEMPERATURE EMBEDDING

E. Carlemalm*, W. Villiger, J.-D. Acetarin and

E. Kellenberger

Department of Microbiology

Biozentrum

University of Basel

Klingelbergstrasse 70

$\mathrm{CH}-4056$ Basel, Switzerland

Phone no.: 253880

\section{Abstract}

The Lowicryl resins $\mathrm{K} 4 \mathrm{M}$ and HM20 are methacrylate/acrylate based formulations which can be used for embedding biological material at low temperature in conjunction with either the progressive lowering of temperature (PLT) technique or with freeze-substitution. The resins are applicable over a very extended temperature range, approximately $210^{\circ} \mathrm{K}$ to $340^{\circ} \mathrm{K}$. Even lower temperatures down to $\mathrm{ca}$. $190^{\circ} \mathrm{K}$ can be reached with two new resins, $\mathrm{K} 11 \mathrm{M}$ and HM23. Test embeddings of unfixed material after freeze-substitution have given promising results which could be useful for immunocytochemical labeling. Lipid extraction is small or absent when the two new resins are used in combination with freeze-substitution.

Key Words: Low temperature embedding, Lowicryl, K4M, HM20, KIlM, HM23, embedding resins, freeze-substitution, immunocytochemistry.

*Address for correspondence:

For reprints and other information, please contact E. Carlemalm at the above address.

\section{Introduction}

One of the frequently used preparation techniques in biology is thin sectioning of resin embedded material. This procedure involves replacement of œllular water by organic dehydration liquids and embedding resin. The classical procedure is performed in a temperature range from $273^{\circ} \mathrm{K}$ to $350^{\circ} \mathrm{K}$, conditions known to be deleterious to the fine structural details even after chemical fixation. The biologically relevant resolution is rarely better than $5 \mathrm{~nm}$ in such preparations. One way to improve the situation is to apply reduced temperatures during the preparation procedure. The rationale for this is described in another contribution to this symposium (Kellenberger et al. 1986). The interest of low temperature methods for embeddings has been recognized for a long time (FernandezMoran 1959, Bullivant 1960, Rebhun 1961) but the progress was, until some 5 to 10 years ago, very slow. One of the reasons was the lack of suitable embedding resins that could be applied at sufficiently low temperatures. The resins used in the standard embedding procedure are all developed to be used for engineering and have too high viscosities and freezing points to be infiltrated at low temperatures. Our group in Basel has thus developed a set of resins suitable for low temperature applications (Carlemalm et al. 1982). Two of them are commercially available under the name of Lowicryl K4M and HM2O . Embedding with Lowicryl K4M and HM2O

Our resin formulas are based on crosslinked methacryl- and acryl-esters. Chemical versatility, low freezing points and viscosities, were the reasons for this choice. The resins can be used within a very extended temperature range, approximately $210^{\circ} \mathrm{K}$ to $340^{\circ} \mathrm{K}$. At the lower temperatures, below $280^{\circ} \mathrm{K}$, the polymerization is achieved by long wave UV-irradiation in conjunction with a photoinitiator. In the upper part of the temperature range, above about $280^{\circ} \mathrm{K}$, thermal polymerization is recormended. The broad application spectrum of the resins is shown in Fig. 1.

our first low temperature procedure with the resins was the so-called progressive lowering of 


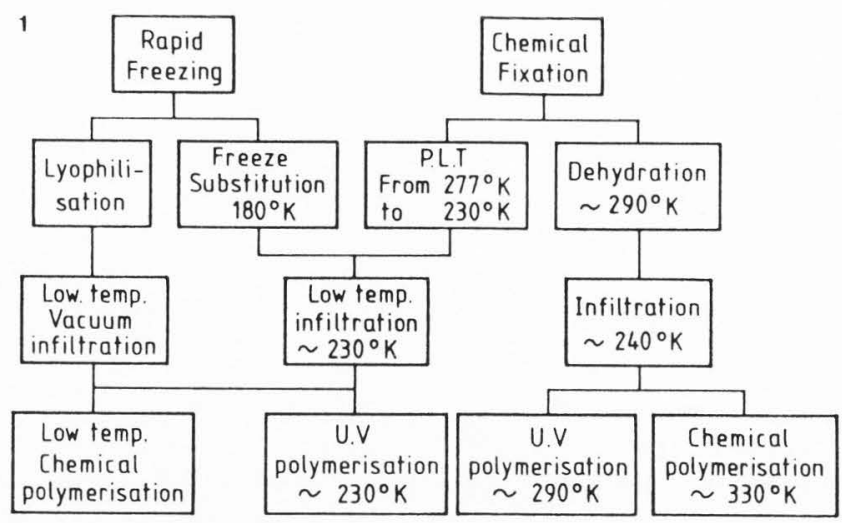

Fig. I A scheme showing the various procedures in which the Lowicryl K4M and HM20 can be applied.

temperature, "PLT", in which the dehydration of the aldehyde fixed tissue starts at $273^{\circ} \mathrm{K}$. The consecutive dehydration steps are done at progressively lower temperatures, always taking care that the interior of the specimens equilibrate with the dehydrating agent in each step before they are transferred to the next one in order to avoid freezing of the tissue, i.e. the temperature in a subsequent dehydration step is not allowed to be lower than the freezing point of a previous step. By observing this very simple rule it is possible to design dehydration and infiltration procedures for a variety of dehydration solvents. With the polar K4M we have found that one can use methanol, ethanol, ethylene glycol, dimethylformamide and acetone, only to mention the few which have been tested. According to solvent-resin compatibility other solvents could be used. Mixtures of solvents can obviously also be considered if that is found to be suitable. The non-polar HM20 enforces some restrictions in the choice of the dehydrating agents, where ethylene glycol and glycerol cannot be recormended. The viscosity of the cold resins sets the lowest usable infiltration temperature for $\mathrm{K} 4 \mathrm{M}$ and $\mathrm{HM} 20$ to about $230^{\circ} \mathrm{K}$ and $210^{\circ} \mathrm{K}$ respectively. The chemical reactivity of both resins limits the lowest usable polymerization temperature to $220^{\circ} \mathrm{K}$.

In Figs. 2 and 3 we show some examples of aldehyde fixed and "PLT" embedded tissues.

Our resins have, besides applications in oonjunction with the "PLT" technique, been successfully used in combination with freeze-substitution of muscle (Humbel et al, 1983) and cartilage (Hunziker et al., 1984; Hunziker and Schenk 1984).

Still another application of the Lowicryl resins is low temperature embedding of freeze-dried tissues for electron microprobe analysis (Wroblewski and Wroblewski 1984).

Even lower temperatures with new resins

Encouraged by the results achieved with K4M and HM20, it was obvious to ask if further improvements could be attained with still lower temperatures. Two new resins, a polar one, $\mathrm{k} 11 \mathrm{M}$ and the non-polar HM2 3 were developed along the same lines as the Lowicryls, with viscosities which permit their use down to $210^{\circ} \mathrm{K}$ and $195^{\circ} \mathrm{K}$ respectively.
The resins have so far only been applied on bacteria with and without bacteriophage infection. This is a tough test of an embedding technique due to the almost unfixable nucleoid (for more details see below) and the relatively high resolution required to see structural details of virus related particles.

Already from these first tests of the new resins with the "PLT" technique we learned that a further lowering of the final temperature, from $235^{\circ} \mathrm{K}$ to $210^{\circ} \mathrm{K}$, gives some improvements in the structural preservation of the bacterial nucleoid. But this temperature reduction is not sufficient to prevent aggregations in the very sensitive DNA pool (Fig. 4, compare also Fig. 5B). It seems that the relatively high temperatures during the early dehydration steps are the critical parts of the "PLT" procedure.

A route to circumvent dehydrations close to $273^{\circ} \mathrm{K}$ is offered by freeze-substitution. Its combination with $\mathrm{K} 11 \mathrm{M}$ gives hope that one can embed without any chemical fixation at all and still get good st nictural preservation (Fig. $5 \mathrm{C}$ ). Fixation for low temper ature embedding

The goal of chemical fixation is to counteract the structural rearrangements due to dehydration and resin infiltration by inter and intramolecular cross-linking. Since one of the goals of our embedding procedures is the imaging of unstained material (without osmium, uranyl, lead or other heavy metals contributing to contrast) and the other to optimise on-section immunocytochemical labeling, aldehyde is our choice of fixative, despite knowing that no fixative exists that renders structures invulnerable to the rearranging effects of dehydration; some freedom of movement is always left. We have to be aware also that several biological substances react insufficiently with aldehydes so as to allow for enough cross-linking, as e.g., nucleic acids, polysaccharides and lipids. Embedding of cells, containing large amounts of such substances, at ambient temperature leads to aggregation and in the case of lipids to extraction. Fig. $5 \mathrm{~A}$ shows an aldehyde fixed T4 bacteriophage infected $\mathrm{E}$. coli cell, our test material, embedded in Epon at roam temperature. The phage-DNA pool in these cells is particularly prone to aggregation, and thus presents an excellent test material. This sensitivity is probably due to the low protein content of the DNA pool which does not allow to form a stably cross-linked gel with aldehyde. Fig. 5B ("PLT") and Fig. 5C (freezesubstitution) illustrates how the application of low temperature reduce and even eliminate the aggregation of the DNA-plasm of the nucleoid.

Another effect of fixation is the chemical modification of the fixed molecules. Charge patterns on the surface of proteins, due to amino groups, are changed when they react with the aldehyde. One could expect that this should lead to major alterations of the interactions between the molecules and thus rearrangements. X-ray studies of aldehyde fixed protein crystals have shown that this is fortunately not the case; only minor changes in the order of a few Angstroms, were observed (Langen et al., 1975; Steitz et al., 1967; Wiskner et al., 1975). Chemical modification might be of larger significance for immocytochemical localisation of antigens on sections. 


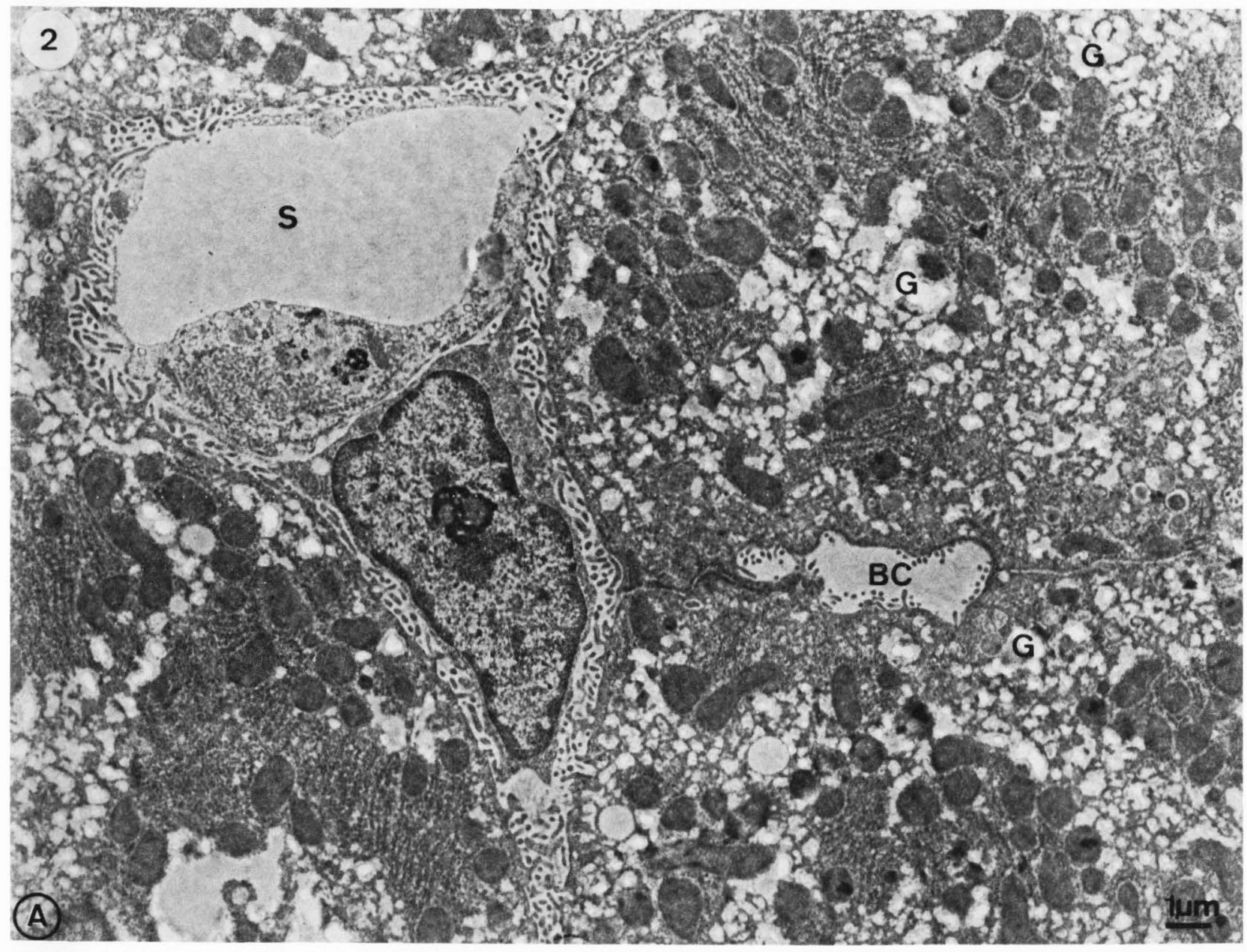

Fig. 2 Rat liver perfusion fixation with 4\% formaldehyde - $0.05 \%$ glutaraldehyde (no osmium tetroxide) section-stained with uranyl and lead acetate. Overview at low magnification (A) shows several hepatocytes with cytoplasm focally within glyoogen (G). Neighbouring hepatocytes form a biliary capillary (BC). In addition a sinus (S) with lining cells and space of Disse to be seen. (B) at higher magnification details of the cytoplasm such as cisternae of the rough endoplasmic reticulum, mitochondria and a peroxisome $(*)$ can be recognized. The arrowheads point to a gap junction. (By courtesy of Dr. J. Roth) .

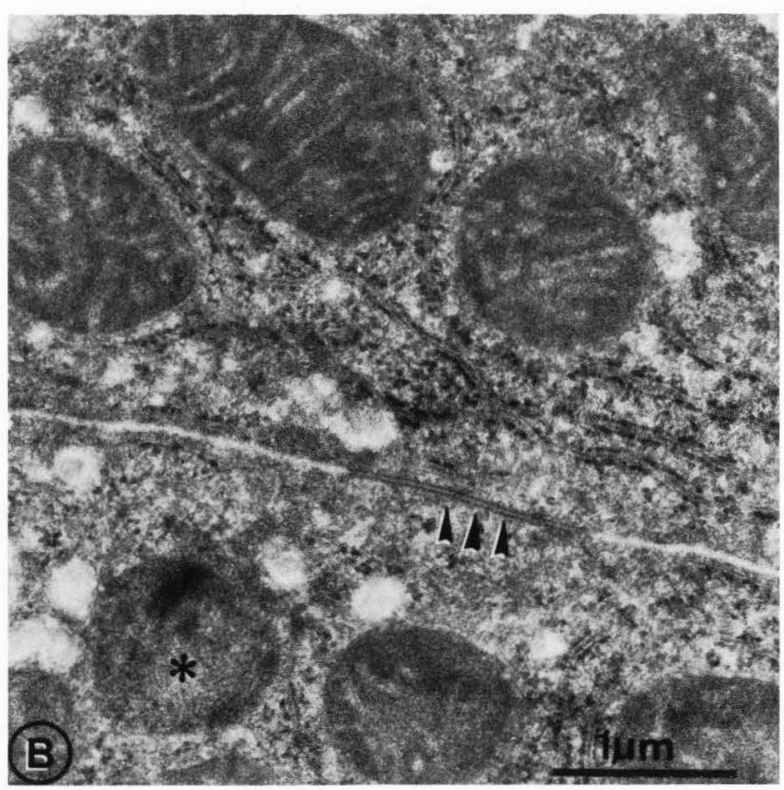


E. Carlemalm, W. Villiger, J-D. Acetarin, et al.
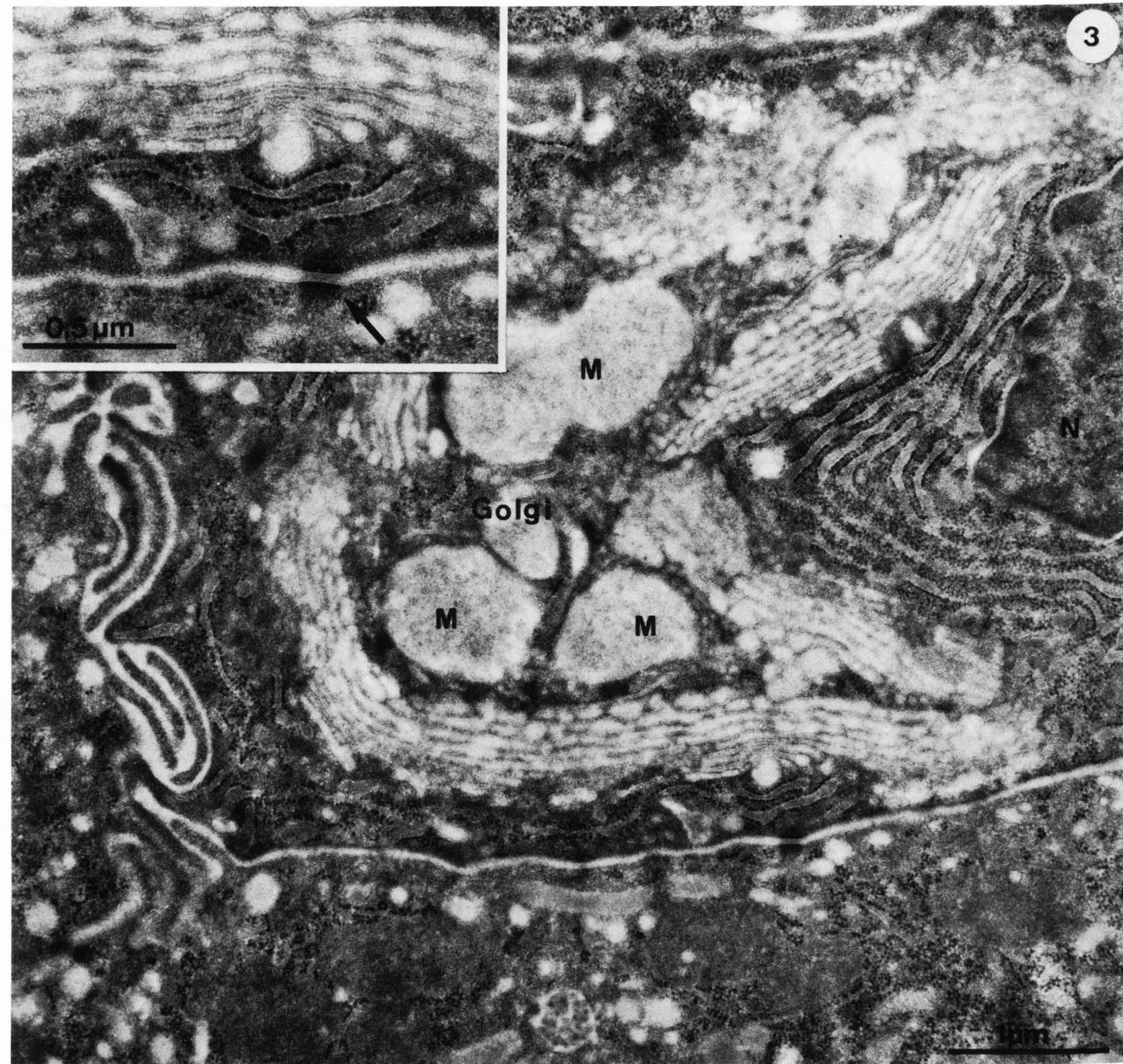

Fig. 3 Rat colon, immersion fixation with $3 \%$ formaldehyde - $0.1 \%$ glutaraldehyde (no osmium tetroxide). Sections stained with uranyl and lead acetate. Prenuclear region of mucin producing goblet cells. Several cisternae of rough endoplasmic reticulum and some Golgi apparatus can be seen together with forming mucin droplets (M). The inset shows part of a Golgi apparatus at higher magnification which consists of a stack of several cisternae. Note the well preserved membrane structure. The arrow points to a desmosome. N-nucleus. (By courtesy of Dr. J. Roth).

Extraction of material during embedding

Extraction of cellular macromolecules, such as proteins and DNA, is very unlikely, as they cannot pass the membranes of the cell or of the organelles as long as these are intact. In order to pass, the macromolecules would have to be cut into so small fragments that they are comparable in size to the small molecules and ions in the cytoplasmic sap. Indeed a large proportion of these small molecules and inorganic ions can easily leave the cell by diffusion as soon as the pumping activity of the membranes is internupted by a fixative. Investigations by Moncany (1982) show that the ion pumps in the membranes are left wide open after their first contact with a fixative, probably before the rest of the cell is fixed. This leads to an equilibration of the ion concentration between the inside and the outside of the cell which can cause 


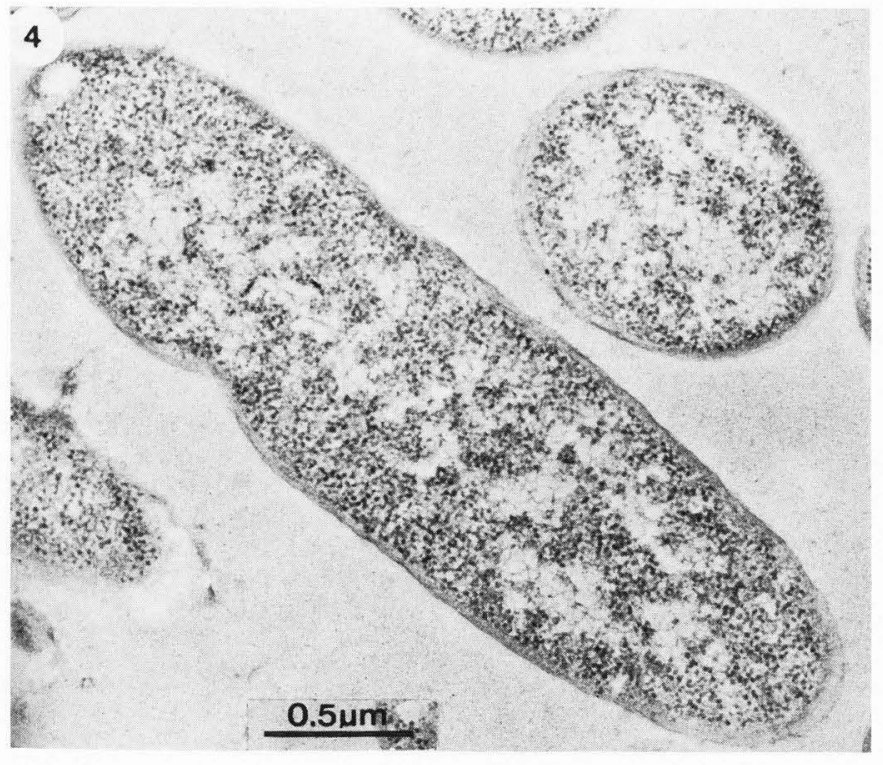

Fig. 4 An aldehyde fixed E. coli cell embedded with the "PLT" technique in the new polar resin $\mathrm{KIIM}$ at $210^{\circ} \mathrm{K}$.

depolymerization of still unfixed organelles that are dependent on a particular ionic strength for their structural integrity, e.g., microtubula and intracellular filaments.

Lipid extraction during various classical embedding conditions have been studied by Cope and Williams (1968). It was investigated for "PLT" and freeze-substitution conditions by Weibull et al. (1983, 1984) who showed that nearly all or all of the lipids are lost when aldehyde fixed cells are embedded with the "PLT" technique. They found, however, with freeze-substitution at $190^{\circ} \mathrm{K}$ or below, only a very small (25\%) loss of lipid or no detectable loss.

The loss of membrane lipids might only eventually lead to rather drastic consequences. Let us assume that we loose the lipids in a very prote in rich membrane, where the proteins are close enough to each other to be cross linked by the fixative. In this case it is reasonable to assume that the protein structure of the membrane will stay intact enough to provide significant biological information. The lipids are simply replaced by the resin as it also replaces the cellular water. In the case of a lipid rich membrane the extraction leads, in the worst case, to solubilization of the membrane and to a total loss of its structure; the proteins are too far away from each other to be cross-linked. In this context it might be of interest to mention that the melamine resin introduced by Bachhuber and Frösch (1982) seems to preserve lipids at "classical" embedding temperatures.

Low temperature embedding and immunocytochemical labeling

The routine application of the "PLT" embedding technique to immunocytochemistry has recently been reviewed by Roth (1982) and Armbruster et al, (1984) and need not be repeated here.

The possibility to rise the detecting sensitivity of the immuno- labeling technique with help of freeze-substitution and low temperature embedding in Lowicryl $\mathrm{K} 4 \mathrm{M}$ is shown in Fig. 6. where the localization of groE, a cytoplasmic protein in E. coli, is compared between formaldehyde fixed, "PLT" embedded cells and freeze-substitution with formaldehyde in the substituting acetone. The substitution was done at $190^{\circ} \mathrm{K}$ and the temperature was subsequently raised to the infiltration temperature for $\mathrm{K} 4 \mathrm{M}, 235^{\circ} \mathrm{K}$, with the fixative present. Counts of labeling density show that the freeze-substituted cells are twiœ as densely labeled as the "PLT" embedded ones, 19 and 10 colloidal gold particles per $\mu \mathrm{m}^{2}$, respectively (Hobot, unpublished results, private communication). Whether this increased sensitivity is caused by the low temperature alone and/or the low reactivity of the aldehydes at these temperatures leading to a very mild fixation and a minimum of chemical modification of the antigen - cannot yet be unambiguously decided by this experiment.

Low temperature embedding with "PLT" or freezesubstitution, some concluding remarks

A comparison between "PLT" and freezesubstitution in association with low temperature embedding shows that the "PLT" process offers some practical advantages. Freezing with its risks of ice crystal formation, is not involved, "PLT" is technically less demanding and a large number of samples can be processed in a relatively short time. All these properties have contributed to make "PLT" a routine method in immunocytochemistry.

Freeze substitution, followed by low temperature embedding, gives promising results but cannot yet be regarded as a routine method as it is still too delicate and elaborate.

The introduction of cryomethods into the embedding techniques gives the microscopist access to more and new information, but at the price of rising costs, technical delicacy and time consumption. The need to choose the adequate "tool" that provides the appropriate information to solve the problem under investigation is larger than ever.

\section{Acknowledgements}

We gratefully acknowledge the skilled technical assistance of Mrs. R. Gyalog, the photographic work by Mrs. M. Steiner and the typing of the manuscript by Mrs. R. Niederhauser. This work was supported by grants from the swiss National Science Foundation.

\section{References}

Armbruster BL, Kellenberger E, Carlemalm E, Villiger W, Garavito RM, Hobot JA, Chiovetti R, Acetarin JD. (1984). Lowicryl Resins - Present and Future Applications: In: Science of Biological Specimen Preparation for Microscopy and Microanalysis. Proceedings of the 2nd Pfefferkorn Conference, Traverse City, MI, Revel JP, Barnard $\mathrm{T}$, Haggis $\mathrm{GH}$, Bhatt SA, (eds.) Scanning Electron Microscopy, Inc. AMF O'Hare, IL USA, pp. 77-81 . 
E. Carlemalm, W. Villiger, J-D. Acetarin, et al.

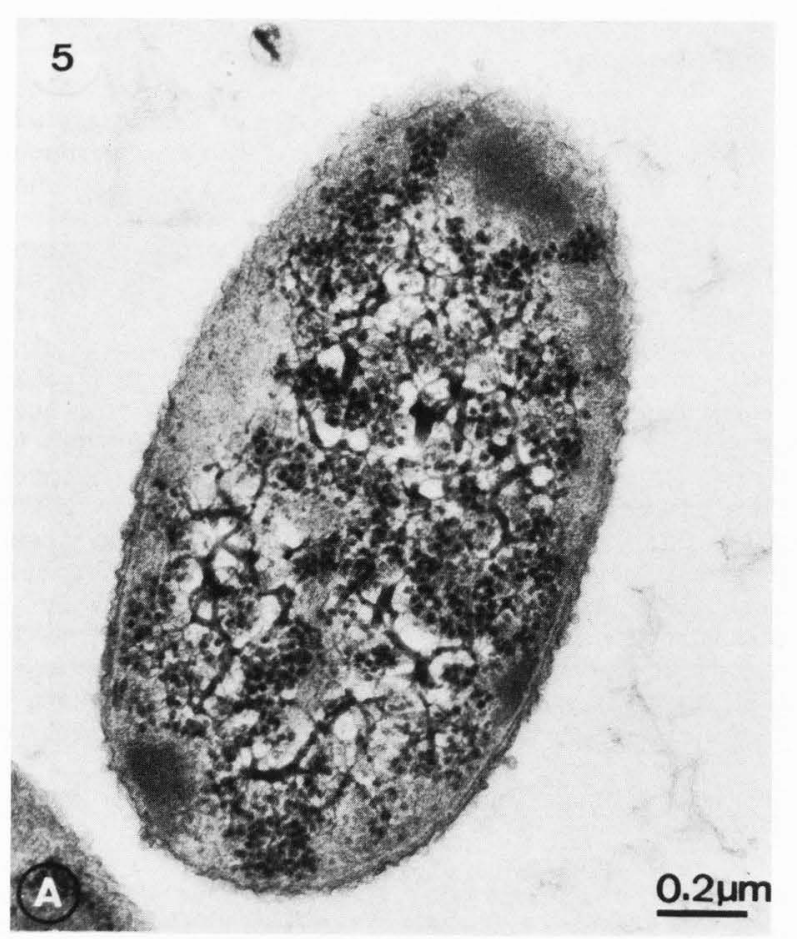

Fig. 5 our test object (see text), bacteriophage T4 infected E. coli cells, embedded with different techniques, demonstrating the influence of the preparation procedure on the DNA pool. Fig. 5A. Aldehyde fixation followed by standard Epon embedding. Fig. 5B is the same fixation but embedded in K4M according to the "PLT" technique. Fig. 5C. Chemically unfixed cell freeze-substituted and low temperature embedded in the new resin KIIM at $210^{\circ} \mathrm{K}$. Note the difference in appearance of the DNA pool due to the preparation procedure.
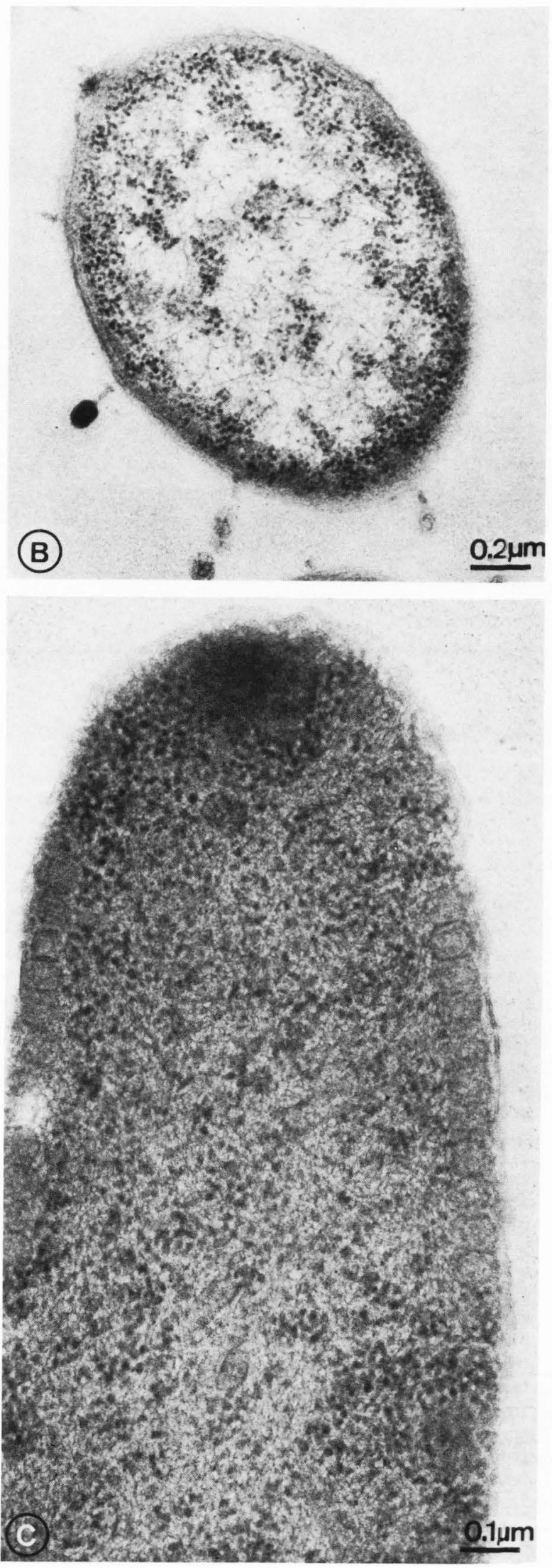

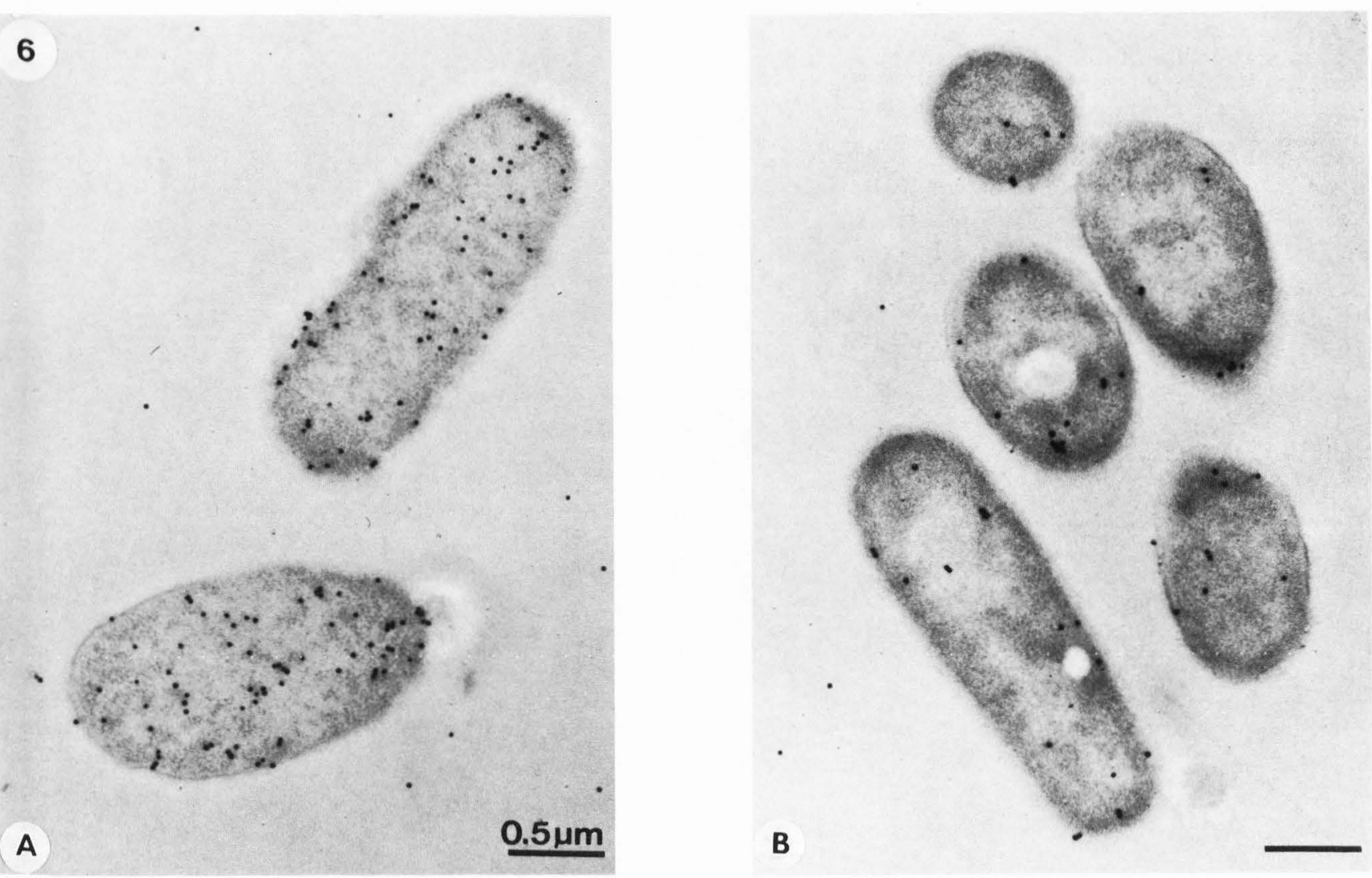

Fig. 6 Comparison of immunocytochemical labeling of the protein groE in E. coli cells after freeze-substitution, Fig. 6A, and "PLT" Fig. $6 \mathrm{~B}$, and low temperature embedding in $\mathrm{K} 4 \mathrm{M}$. Note the clearly higher labeling intensity of the cells in 6A (courtesy of Dr. J. Hobot).

Bachhuber K, Frösch D. (1982). Melamine resins, a new class of water-soluble embedding media for electron microscopy. J. Microscopy 130, 1-9.

Bullivant S. (1960). The staining of thin sections of mouse pancreas prepared by the Fernandez-Mor an helium II freeze-substitution method. J. Biophys. Biochem. Cytol. 8, 639-647.

Car lemalm E, Garavito RM, villiger W. (1982). Resin development for electron microsoopy and an analysis of embedding at low temperature. $\mathrm{J}$. Microscopy $126,123-143$.

Cope GH, Williams MA. (1968). Quantitative studies on neutral lipid preservation in electron microscopy. J. Roy. Microsc. Soc. 88, 259.

Fernandez-Mor an H. (1959). Cryofixation of supplementary low-temperature preparation techniques applied to the study of tissue ultrastructure. J. Appl. Physiol. 30, 2038.

Humbel B, Marti TH, Müller M. (1983). Improved structural preservation by combining freeze substitution and low temperature embedding. In: Pfefferkorn, G. (ed.) BEDO, Vol. 16, 585-594, EDO, Antwerpen.

Hunziker EB, Hermann W, Schenk RK, Mueller M, Moor H. (1984). Cartilage Ultrastructure after High Pressure Freezing, Freeze Substitution, and Low Temperature Embedding. I. Chondrocyte
Ultrastructure-Implications for the Theories of Mineralization and Vascular Invasion. J. Cell Biology 98, 267-276.

Hunziker EB, Schenk RK. (1984). Cartilage Ultrastructure after High Pressure Freezing, Freeze Substitution, and Low Temperature Embedding. II. Intercellular Matrix Ultrastructure-Preservation of Proteoglycans in Their Native State. J. Cell Biol. $98,277-282$.

Kellenberger E, Carlemalm E, Villiger W. (1986). Physics of the preparation and observation of specimens that involve cryo-procedures. In: Science of Biological Specimen Preparation 1985 (eds.) M. Mueller et al., Proceedings of the 4th Pfefferkorm Conference, Grand Canyon, 1985. SEM, Inc., AMF O'Hare, IL. pp. 1-22.

Langen R, Poppe CH, Schramm HJ, Hoppe W. (1975). Electron microscopy of thin protein crystal sections. J. Molec. Biol. 93, 159.

Moncany M. (1982). Determination des conditions intracellulaires chez E. coli. Consequences biologiques de leur modification. Ph.D. thesis at Universite Paris VII.

Rebhun LI. (1961). Applications of freezesubstitution for electron microscopy studies of invertebrate ocytes. J. Biophys. Biochem. Cytol. 9, 785-797. 
E. Carlemalm, W. Villiger, J-D. Acetarin, et al.

Roth J. (1982). The protein A-gold (pAg) technique - A qualitative and quantitative approach for antigen localisation on thin sections. In: Techniques in Immunocytochemistry Bullock GR, Petrusz P, (eds.) Vol. 1, pp. 107-133. Academic Press, London.

Steitz TA, Ludwig ML, Quiocho FA, Lipscomb WN. (1967). The ultrastructure of carboxypeptidase A. J. Biol. Chem. 242, 4662 .

Weibull C, Christiansson A, Carlemalm E. (1983). Extraction of membrane lipids during fixation, dehydration and embedding of Acholeplasma laidlawii-cells for electron microscopy. J. Microscopy 129, 201-207.

Weibull C, villiger W, Carlemalm E. (1984). Extraction of lipids during freeze-substitution of Acholeplasma laidlawii-cells for electron microscopy. J. Microscopy 134, 213-216.

Wiskner BC, Ward KB, Lat tman EE, Love WE. (1975). Crystal structure of sickle-cell deoxyhemoglobin at $5 \AA$ resolution. J. Molec. Biol. 98, 179.

Wroblewski R, Wroblewski J. (1984). Freeze drying and freeze substitution combined with low temperature embedding. Histochem. 81, 469-475. 